\title{
Quando canto é reza, quando reza é canto: identidades negras e sacralidades poéticas
}

Gean Paulo Gonçalves Santana fratergean@yahoo.com.br

Universidade do Estado da Bahia - UNEB, Teixeira de Freitas, Bahia, Brasil.

\begin{abstract}
RESUMO
Os cantos-poemas, construídos a partir de experiências intersubjetivas, ora são respostas, ora são questionamentos às circunstâncias históricas, socioafetivas e aos confrontos da vida cotidiana dada a sua sacralidade. Descrever essa poética, no que traz de expressões que lidam com a representação da herança africana, suas identidades, ressignificações e resistência, constitui-se objeto de estudo do percurso discursivo metodológico deste texto. Destaca-se, nesse trabalho, o papel que o canto-poema revela em relação à comunidade quilombola do Extremo Sul da Bahia e às comunidades negras da Região do Pacífico do Valle Del Cauca. As análises que sustentam esse trabalho dialogam com as teorias da tradição viva, poética da oralidade, e estudos culturais. Os cantos-poemas, como instrumento poético, explicitam histórias ancestrais, louvores e orações.
\end{abstract}

PALAVRAS-CHAVE: Canto-poema. Religiosidade. Resistência. Ancestralidade. 


\section{INTRODUÇÃO}

Os conhecimentos do sagrado mantido pelos povos africanos contribuíram para fomentar processos culturais de resistência, dentre os quais um complexo sistema litúrgico como elemento da tradição viva. A religiosidade incorporada em todos os aspectos da vida, parafraseando Padilha (2007), cartografa-se, desse modo, as identidades em diferença que a colonialidade do poder e do saber tentou, em vão, esfacelar.

O canto como reza, como sopro da voz é criador e, como tal, revela uma experiência temporal de manutenção da tradição ancestral e experimentação da mesma, por isso é "força vital, vapor do corpo, liquidez carnal e espiritual, no qual toda atividade repousa, se espalha no mundo ao qual dá a vida" (ZUMTHOR, 2010, p. 66).

No canto, encontra-se a palavra força. Conceptualmente, aqueles que fazem uso da palavra, referindo-se às culturas africanas e afro-brasileiras, muitas vezes, pronunciam-na em forma de canto, fecundando seus atos, de modo que "a palavra proferida pela Voz cria o que diz" (ZUMTHOR, 2010, p. 66). Não obstante, o canto encarna-se como memória viva, seja para o indivíduo a quem a imposição de sua voz deu forma, seja para o grupo, cuja linguagem constitui a energia ordenadora, princípio dinâmico, que contribui para a manutenção identitária. O princípio dinâmico que constatamos no canto, aqui nomeado de terceiro elemento, remetenos à força transformadora, existencial e imanente de Ėsù que nos foi apresentada por Juana Elbein dos Santos (1976).

Apropriando-nos do termo phármakon, essa medicina, por Derrida (2005) denominada de filtro, aqui traduzido por canto, já se introduz no corpo do discurso com toda sua ambivalência, alternada ou simultaneamente, benéfica e maléfica. Essa virtude de fascinação, uma potência de feitiço, encontra ressonâncias junto aos diolas de Kong'; para eles, a função performática da palavra "corresponde à expressão de um poder social efetivo: palavra do chefe que legisla e executa os julgamentos, palavra do sacerdote ou do mago que abençoa, amaldiçoa ou até mesmo cura ou mata" (DERIVE, 2010, p. 28).

A palavra força, princípio dinâmico do canto que penetra os corpos e os coloca em movimento, considerando a importância da cadeia de transmissão, matriz e motriz das tradições dos povos afrodescendentes, faz parte do alicerce sobre o qual se construiu o edifício da cultura. Por isso, apropriando-nos de Padilha (2007, p. 37), "praticá-la foi mais que uma arte: foi um grito de resistência e uma forma de autopreservação dos referenciais autóctones, ante a esmagadora força do colonialismo". Não ao acaso, o canto, parábola de poder e mistério, "considerada como a materialização, ou a exteriorização, das vibrações das forças" (HAMPATÉBÂ, 2010, p. 172), oscila entre devir e continuidade, em perpétuos movimentos com o propósito de "restaurar o equilíbrio perturbado e restabelecer a harmonia" (HAMPATÉ-BÂ, 2010, p. 173). O canto sob a égide da ancestralidade africana é "agente ativo da magia", pois, "assim como a fala divina de MaaNgala, [...] a fala humana anima, coloca em movimento e suscita as forças que estão estáticas nas coisas" (HAMPATÉ-BÂ, 2010, p. 173).

O corpus para este estudo refere-se aos cantos-poemas que constam no DVD - Bahia" (2014) e aos cantos ancestrais afro-colombianos do Valle Del Cauca, região 
do Pacífico. No percurso discursivo metodológico, utilizaremos o termo cantopoema, com o intuito de representar a realidade da expressão poética oral desses espaços afro latinos americanos. $\mathrm{O}$ uso do termo se dá em virtude do diálogo que estabelecemos com as reflexões de Edmilson Pereira (2002) e, por acreditarmos que se trata de "um corpus literário" (SANTANA, 2014, p. 23), também, em virtude da importância atribuída à letra e à melodia que permeiam a vivência cotidiana desses povos.

Os cantos-poemas presente nas comunidades quilombolas do Extremo Sul da Bahia e nas comunidades negras do Valle Del Cauca, região do Pacífico Colombiano, resistindo à força do colonialismo, tornaram-se marcas identitárias e de resistências do povo negro. É nosso propósito apresentar uma análise de possíveis diálogos entre os cantos-poemas dessas regiões, de colonização lusa e hispânica, que trazem elementos que cartografam a história e memória ancestral afrodescendente.

Após 1851, com a supressão da escravatura, os afro-colombianos que ocuparam as margens dos rios estabeleceram um acordo de coexistência com os assentamentos indígenas espalhados que conseguiram sobreviver ao desastre ocasionado pela invasão espanhola. Esses grupos, ainda na atualidade, vivem em condições de pobreza. A região do Pacífico colombiano possui, em sua maioria, uma população afrodescendente.

O processo de colonização, às margens do Atlântico e, posterior, o seu desdobramento com a formação de grandes propriedades dos senhores de engenho, deu fim, quase que por completo, à mata atlântica que compunha o território de Identidade do Extremo Sul da Bahia. A exemplo da Região do Pacífico colombiano, esse território possui uma variedade de água e apresenta uma grande diversidade étnica e cultural; na zona costeiras estão comunidades pataxó e, no interior do continente, comunidades quilombolas que, após um processo conflituoso de reconhecimento identitário, tornaram-se legalmente Comunidade Remanescente de Quilombo, em 6 de abril de 2005, conforme portaria no 7, da Fundação Cultural Palmares e publicação no Diário Oficial da União, № 74, secção 1. A população dessas comunidades, em sua maioria negra, é oriunda da Colônia Leopoldina (1818), uma sesmaria de posse suíço-alemã, situada ao longo do Rio Peruípe, formada por 38 fazendas de cultivo de café, de posse suíço-alemã, e que, de acordo com inventário Mantandon, de 1858, havia escravos repatriados de origens jêje, cabinda, manjolo, benguela e nagô (SANTANA, 2018).

Os negros que compõem essas comunidades descendem de ancestrais escravizados que foram trazidos por navios negreiros e/ou através das negociações do sistema escravagista para produção de café e que resistiram, no tempo e no espaço, ao trabalho escravo e ao sistema que o alimentou, formando os quilombos. Não diferente, os negros, ao chegarem em solo colombiano, resistiam ao processo escravocrático, lutaram e fugiam, constituindo palenques, espaços de resistência e de manutenção das identidades. Tanto nos quilombos brasileiros, como nos palenques colombianos, os cantos-poemas tornaram-se conotações "mágico-religiosas, filosóficas y festivas (ZAMBRANO, 2003, p. 22).

Observando as particularidades dos processos civilizatórios ocasionados pelas colonizações luso e hispânica, os dados revelam forte presença negra e indícios de um período que guarda, nos rituais religiosos e culturais, marcas da ancestralidade africana, das identidades e da resistência. 


\section{NO BATUQUE DA VIDA}

O ritmo é constituinte da arte inerente à poética das mulheres afrocolombianas da região do pacífico e das cantadoras das comunidades quilombolas do Extremo Sul da Bahia, porque "es consustancial a la imagen; es el que realiza, el que une en todo el signo y el sentido, la carne y el espíritu (SENGHOR, 1970, 221). Compreendemos, por isso, a importância destinada aos instrumentos de percussão que acompanham a voz humana, seja nos registros dos poemas e na própria estética sonora, pois o efeito torna-se um ato reflexivo sobre os sujeitos que "siente que siente, siente su existencia, se siente a sí mismo" [...], pois "el ritmo negro-africano se define, precisamente, por su carácter vital [...] el arte no es solamente social, sino vital, [...] no sólo la producción material, sino también la producción espiritual" (SENGHOR, 1970, p. 225-294).

Nas palavras encarnadas, sejam as dos cantos-poemas quilombolas em terras brasileiras, sejam as da poética afro-colombianas, percebemos que o ritmo faz todo ser estremecer e "expresa la fuerza vital". Não obstante, Catalina Gonzáles Zambrano (2003), citando Alejo Carpentier, referindo-se à música no período da escravidão, e que, não arbitrário, entendemos como poética negra na diáspora, reverbera:

La música fue música antes de ser música. Pero fue música muy distinta de lo que hoy tenemos por música deparadora de un goce estético. Fue plegaria, acción de gracia, encantación, ensalmo, magia, narración escandida, liturgia, poesía, poesía-danza, psicodrama, antes de cobrar (por decadencia de sus funciones más bien que por adquisición de nuevas dignidades) una categoría artística (ZAMBRANO, 2003, p. 4).

Com o canto-poema, as cantadoras pedem passagem a Calunga ${ }^{2}$, ao pássaro Sankofa e aos Tambores e evocam a força presente "en los toques y los silencios del tambor o en los ritmos musicales de canoas y canaletes en aguas de ríos y mares" (FRIEDEMANN, 1997, p. 21). Com a poética da voz, celebram a força transformadora e imanente de Ėsù ${ }^{3}$ gênese da existência diferenciada que mobiliza, comunica, propulsiona as relações elementares vitais à poética da voz, e o seu movimento bantu, mundo de Zambi, ngomas, calunga; e também, jejeiorubano, vindo em linha direta dos velhos e veneráveis orikis de orixá e tantas outras representações do sagrado existencial pelos afrodescendentes.

Ainda sobre Calunga, em relação as terras afrocolombianas, Friedemann (1997) assim nos esclarece:

La evocación de siluetas de deidades del pasado africano de los palenqueros [...]: eee calunga manquisé/ arió negro congo chimbumbé nos refiere la presencia de Calunga, término de origen $\mathrm{Ki}$ Mbundo que representa un dios del mundo bantú. [...] entre gentes del Congo. Allí, [...] sus gentes conciben la tierra como una montaña sobre un cuerpo de agua que es el sitio de los muertos. Así entre la tierra y los vivos y el lugar de los espíritus de los muertos las aguas que corren se convierten en caminos o puentes. $Y$ el paraje de los muertos está en Calunga, abajo, en el agua, debajo de la tierra. [...] El ritmo y el baile de muerto en el lumbalúde Palenque de San Basilio que simula desplazamientos acuáticos convalida allí mismo la figura 
de Calunga, como una huella de africanía. (FRIEDEMANN, 1997, p. 2223).

«Eee calunga manquisé/arió negro Congo chimbumbé» es un canto de despedida en el ritual funéreo del Lumbalu donde se plasma el protagonismo del agua en la expresión poética afroamericana: el paso trasatlántico aunado en el pensamiento cosmológico de Calunga, deidad de la muerte en océanos y mares en los universos bantúes como el Ki-Mbundu. Y la evocación de "chimbumbé» un espíritu acuático en posesión del difunto, dentro del periplo acuático de un continente a otro, y del mundo terrenal al mundo de las aguas. Al regreso, en la oscuridad de la noche el eco del canto de despedidadel lumbalú[...], tomó la dimension metafísica de un puente lumínico entre África y Colombia.(FRIEDEMANN, 1996, p. 147).

A forte presença de Calunga nos cantos afro-latinos, e, observando as reflexões em Friedemann, é possível uma aproximação a Nanã Buruquê, cujo sincretismo brasileiro associa à Senhora Sant'Ana, uma santa católica, também muito venerada na região do Pacífico colombiano. Nanã Buruquê é um dos orixás que têm ligação direta com os mortos. A esse respeito, Santos (1976, p. 115) explicita: "Nàná, patrona da lama, matéria-prima da vida, é omo Átióro oké Ofa. Descendente do grande pássaro Àtióro da cidade de Ofa", possui o título de lyálóde, o "mais honorífico que uma mulher pode receber e que a coloca automaticamente à cabeça das mulheres e da representação no áiyé do poder ancestral feminino" (SANTOS, 1976, p. 116) ${ }^{4}$. Por isso, saudamos o grande pássaro Àtìóro e o Sankofa, prenunciando o ritmo dos tambores ngoma, caburé, cununo macho e cununo fêmea, respectivamente, afro-brasileiros e afro-colombianos.

O corpo lançado nas águas, como uma grande oferenda, torna-se insepulto, uma entidade símbolo ${ }^{5}$, pois renasce perenemente nas memórias, corroborando a tradição viva, desvelando a terceira-margem, invisível aos olhos petrificados pelos sistemas escravocráticos, e tão importante à religiosidade e à história de resistência identitária dos povos afro latinos americanos. As reflexões de Santos (1976) aproximam-se das de Friedmann ao nos esclarecer que "a oferenda devolve, transfere ao grande útero fecundado e, consequentemente, a ambos os progenitores míticos universais, não só seres humanos, mas também tudo aquilo que existe como matéria individualizada" (SANTOS, 1976, p. 223).

Não diferente, entendemos que a força vital do grande útero de Calunga, como "las aguas que corren se convierten en caminos o puentes" (FRIEDEMANN, 1996, p. 147), presente como força imanente, seja no canto de despedida de lumbalú, seja em outros, impressos na vida afro-latina da região do Pacífico e nos cantos-poemas das comunidades quilombolas do Extremo Sul da Bahia/Brasil, reverbera a tradição viva, ou seja, "um mundo concebido como um Todo onde todas as coisas se religam e interagem" (HAMPATÊ-BA, 2010, p. 169). O grande mar, útero e berçário da vida, diferindo-se do navio negreiro, com o ritmo de suas águas, "ordena, al mismo tiempo, la totalidad del conjunto hacia la luz del Espíritu" (SENGHOR, 1970, p. 221).

A poética da voz, cujo "som é o resultado de uma estrutura dinâmica, em que a aparição do terceiro termo origina movimento" (SANTOS, 1976, p. 49), é uma forma de luta, rebeldia e resistência ao sistema opressor. 
Nesse sentido, Alfredo Vanín Romero et ali (2010, p. 12) esclarecem:

La música, especialmente la de marimbas y tambores, fue sinónimo de resistencia y se asoció a la rebeldía, por lo que fue perseguida por los españoles. San Pedro Claver, en Cartagena, secuestraba los tambores de los negros. En el Pacífico hay documentaciones tempranas de la persecución y la resistencia: en 1734, en Barbacoas, el padre Larrea ordenó amontonar 30 marimbas y las hizo quemar todas. El padre Mera recorría el Patía y cada vez que encontraba un baile de marimba desembarcaba y la gente tenía que huir al monte para escapar de su "santa ira".

Não diferente, em solo brasileiro,

historicamente, do século XVI ao XXI, muitos terreiros dormem ao som dos tambores. Entretanto, um percurso sociohistórico marcado por perseguições, estigmas de baderna, desordem e feitiçaria, foi se constituindo na sociedade brasileira em torno do tambor e, por extensão aos seus executores. Muitos decretos e atos, públicos ou velados, sancionaram a proibição do seu toque que está diretamente ligado ao batuque, também denominado de samba, em muitos locais. Mario de Andrade, em 1934, referindo-se à fraqueza do samba rural em Pirapora, Estado de São Paulo, notifica que a principal razão da fraqueza derivou da reação dos padres e excesso de repressão policial. Segundo esse autor, estes segmentos da sociedade acabaram expulsando o samba para a periferia da cidade, longe dos centros urbanos. [...] O que ocorreu em Pirapora [...] não foi um fato isolado. Em todo o território brasileiro, os negros, mesmo residindo na periferia, sofreram a força da repressão eclesial e policial. Para percussionarem o tambor, era necessário tirar licença na delegacia, uma obrigatoriedade que se estendeu até 1964 (SANTANA, 2014).

Os tambores incomodam os silenciamentos ocasionados pelo colonialismo e tudo o que ele representa para o povo afrodescendente. Sobretudo, porque ele é síntese de vários elementos, cuja complexidade filia o expectador-ouvinte a uma história da qual intentaram desvinculá-lo. 0 ritmo que ele propaga ritualiza e reatualiza as tradições que guardam a palavra ancestral e que, por isso, promove um reconhecer-se sócio histórico, um sentimento de pertença com sua história e, por conseguinte, com sua gente.

O tambor possui um poder misterioso, por isso cria coisa. Um poder que convoca à luta, um olhar para si, pois o corpo, ao escutá-lo, estremece. No tambor, ideologia e teogonias foram consolidadas, por isso essa ligação viva com o negro, pois nele assenta a força embrionárias e ativadora de memórias. Utilizando as reflexões de Hampatê-Ba (2010), mesmo em outro contexto, é possível dizer que o tambor é palavra viva que possui um carácter sagrado vinculado à sua origem divina e às forças ocultas nele depositadas. Sim, o tambor incomoda, convoca à batalha, à liberdade, pois "en América los tambores no sólo se volvieron el centro de la festividad y la música, sino que se convirtieron en instrumentos para convocar a las huidas y rebeliones" (VANÍN ET ALI, 2010, p. 12).

Zambrano (2003), também referindo-se aos instrumentos de percussão da Região do Pacífico colombiano, assim nos esclarece: 
Bajo el influjo de los dedos fuertes, con marcado acento y ritmo, los hombres golpean los tambores para acompañar una copla, una décima o una fuga. El bombo, con su caja hueca de una pieza y sus sonidos graves, golpea el corazón. El sonajero y los guasás de utilización mágico-religiosa son tocados por mujeres para acompañar sus cantos. La música de la marimba es el espíritu invisible que desde las regiones misteriosas del aire, del agua y de los bosques, actúa para trazar el destino de los hombres, animales y plantas. Estos tambores e instrumentos cantan para que los santos bajen y sean partícipes de los contextos terrenales donde se les adora. La música de los tambores es ofrecida a los santos por los devotos que han recibido un beneficio (ZAMBRANO, 2003, P. 27-28).

Tal realidade encontra ressonância na narrativa de uma cantadora do quilombo de Helvécia, no Extremo Sul da Bahia, ao externar seu sentimento sobre o escutar dos tambores:

Quando eu ouço os tambores, quando eu ouço aqueles cantos, é como se meu corpo, realmente ele se arrepia todo. É mais forte do que eu; é como se eu realmente estivesse ali vivenciando, voltando na história, entrando em contato, relação com meus ancestrais. Então, eu acho que isso é importante. Eu acho que toda a pessoa que é negra ou que também se identifica como tal, ele sente isso, porque eu sinto. Você entendeu? Então, quando eu ouço uma música, que eu vou ao ambiente que toca esses cantos, que eu ouço só de outra pessoa tocar ali no toque do tambor, eu me arrepio dos pés à cabeça. Isso é muito forte pra mim. Isso significa que essa relação, esse contato com os meus ancestrais independe de tudo aquilo que eu aprendi posterior. Vem mesmo, é profundo isso. Eu vejo isso não só em mim, mas com outras pessoas também que eu convivo, né? Que estão diariamente ali, presentes nas atividades que nós desenvolvemos. A gente consegue sentir isso. E é bom sentir tudo isso e saber que a gente, enquanto povo, a gente tem essa relação com toda a nossa história, com todos os nossos antepassados. É isso (SANTANA, 2014, p. 91).

As reflexões de Zambrano aproximam-se das de Roseli, na medida em que, também, entendemos a cultura como "un proceso que crea y recrea una realidad social" e de pertencimento ancestral, de modo que os sujeitos se reconheçam parte da história e não esqueçam de celebrar a tradição viva, cujo ritmo marca memórias de memórias, fluxo temporal de luta e resistência. Dessas reflexões, compreendemos que o tambor é força que imanta o canto-poema como forma de criação, experimentação e re-criação que se move entre intérprete e ouvinte. Não obstante, potencializa a dinâmica da autonomia que lhe é outorgada por expressar processos de percepção, de ressignificação e construção de sentido, a partir da realidade vivencial do eu e do outro, em constantes processos intersubjetivos (SANTANA, 2014). O tambor como elo de pertencimento sócio histórico, e como tradição viva de poder e mistério, é materialização e exteriorização das vibrações de forças em perpétuos movimentos, cujo propósito é restaurar o equilíbrio perturbado e restabelecer a harmonia, por sê-lo "el máximo elemento de 
resistência" (LAVIÑA, 2005, p. 59) nos espaços territorializados pela ancestralidade africana. Não obstante, ele é propulsor da magia, colocando em movimento e suscitando forças que estão estáticas nas coisas, nos espaços e nos sujeitos e, como tal, retroalimenta o pensamento contrário à subserviência.

Entre conflitos e negociações, os cantos-poemas ao toque dos tambores durante as celebrações e no cotidiano existencial da população afrodescendente foram ressignificando os fragmentos identitários nos entrechoques do poder com seus corpos. A vivência desses atos tornou-se, simultaneamente, religiosidade, tradição, empoderamento e resistência identitária, porque, mesmo quando a poesia silencia, "explode por dentro a intensa música dos abismos" (CUTI, 2002, p. 53).

Santana (2018), citando Mário de Andrade (1963, p. 25), em Música de feitiçaria no Brasil, ressalta que música e alquimia são "filhas mais velhas da magia". A palavra cantada, agente da magia, tem relação com o corpo, com o espaço e com o tempo, visto que tudo está em movimento. Na tradição africana, e nos espaços territorializados por ela, "a fala que tira do sagrado o seu poder criador e operativo encontra-se em relação direta com a conservação ou com a ruptura da harmonia no homem e no mundo que o cerca" (HAMPATÉ-BÂ, 2010, p. 174).

\title{
2. RELIGIOSIDADE, HISTÓRIA E MEMÓRIA ANCESTRAL: PARTES INDISSOCIÁVEIS NA/DA VIDA
}

\author{
Chi manlongo (soy de) los del Congo \\ Chi ma (ri) Luango (soy de) los de Luango \\ Chi mariluangori Angola (soy de) los del Congo \\ (soy de) los de Luango (De los de Luango de Angola) \\ Mona mi a baepacasariambé (Mi hijo se ha ido para el cementerio) \\ Eee calunga lungamanquisé \\ Ario negro congo chimbumbé (FRIEDEMANN, 1992, p. 553).
}

Esse canto de lumbalú, ao mesmo tempo em que cumpre o papel de ajudar a alma do defunto a encontrar o caminho que o conduz ao outro mundo, revela o seu pertencimento as terras africanas, fato que cartografa as distâncias abissais da diáspora negra ocasionada pela tormenta da colonização. O canto-poema, como palavra sagrada, considerando sua ocorrência na maioria das civilizações africanas, enquanto palavra viva "tem um poder misterioso, pois palavras criam coisas" (VANSINA, 2010, p. 140). Também, se observarmos o termo lunga e a sua devida relação com o vocábulo que o antecede calunga, e, verificando a etimologia, "radical bantú - lung- dios; água. Cf. kik. Ka(pref.) + kik. Lùngadios supremo, mar, mundo subterrâneo (MOÑIMO; SCHWEGLER, 2002, p. 192), parece que o mesmo indicia uma súplica à divindade bantu Chimbumbe da região do Rio Congo inferior, para que o espírito possa retornar à sua casa, sua terra, sua gente.

Um dos ritos que se realizava nas comunidades quilombolas do Extremo Sul da Bahia sinaliza uma realidade próxima a nossa reflexão sobre o canto-poema "Chi man longo", pois quando morria alguém e a comunidade não podia transladar o corpo, cantava-se para que o espírito encontrasse o caminho de casa para descansar ao lado dos seus (SANTANA, 2014). Assim diz o canto-poema: 


\author{
Uma incelênça \\ Tá pedindo, Senhor Deus \\ Senhora da Soledade, \\ Filha do vosso ventre \\ Correi mundo, \\ Vem contente \\ Oh, bendito sejais (SANTANA, 2014, p. 242)
}

Desse modo, apropriando-nos de Derive (2010), mesmo em outro contexto, podemos dizer que os cantos-poemas, enquanto palavras da tradição, a exemplo do termo genérico kumakóro $0^{6}$, "frequentemente se referem de um lado à história, de outro às práticas rituais da sociedade" (DERIVE, 2010, p. 48).

Entendemos o canto-poema como uma insurgência poética, pois reconduz espíritos, cria e recria caminhos e, ao entrecruzar tempos e espaços distintos é "lugar da palavra tecida [dor, desalento, amor, harmonia]; palavra cuja força é também divina, [...], uma espécie de fuga, lugar de rebeldia" (SEMEDO, 2010, p. 39). Por isso, compreendemo-no como tecido e tessitura da memória, uma marca da tradição que se retroalimenta "na qual todas as coisas religam e interligam, conferem e imprimem a essa memória o caráter de particularidade de ser totalizante" (SEMEDO, 2010, p. 77). Como nos esclarece Santana (2014), ao serem vocalizados, trazem à cena imagens produzidas pela memória do tempo vivido e do tempo contado, por vezes, substituídas, amparadas ou constituídas de sentidos em meio aos relampejos históricos. Os cantos-poemas "oh, bota fogo no engenho", vocalizados nas comunidades quilombolas do Extremo Sul da Bahia, e "Uma fuerza popular" traduzem esse lugar de rebeldia ao estado servil que o processo civilizatório europeu impôs aos negros escravizados e, posterior, aos seus descendentes, na tentativa de usurpar suas consciências e seus "corações de pássaros".

Oh bota fogo no engenho,

Aonde os negros apanhô,

A vida aqui é bom demais, meu Deus do céu!

Aqui, quem manda é os nagô.

Olêlêlêlêlêlê

Olêlêlêlêlêlê

Olêlêlêlêlêlê, meu Deus do céu

Olêlêlêlêlêlê (SANTANA, 2014, p. 186).

Una fuerza popular

El cultivo de la caña

para el pueblo es una carga

el pueblo produce el dulce

pero su vida es amarga

una fuerza popular

vamos todos a formar

una fuerza popular

vamos todos a formar (VELASCO DÍAZ, 2011, p. 22) 
Nas estrofes de ambos os cantos-poemas, observamos uma voz narrativa que denuncia um espaço de servidão histórica acometido aos povos africanos escravizados na América lusa e hispânica, e aos seus descendentes, tanto quanto em muitos outros espaços onde o processo civilizatório europeu imperou. Também, observamos que o labor e a dor dividiam o mesmo espaço, explicitando o estado de escravidão.

Se por um lado notamos os estilhaços da escravidão, por outro, percebemos nas palavras cantadas "bota", no primeiro canto-poema, e "vamos", no segundo, uma dimensão conativa, e, como tal, propulsora do rompimento das inércias sociais e dos mecanismos ideológicos que insistem em manter estruturas coercivas. Evocando o conceito de palimpsesto, esses versos revelam muitos outros registros que a história, sob o olhar e escrita do colonizador, tentou extirpar, condicionando o negro ao silenciamento através do trabalho forçado e pelas imposições ideológicas, de modo a submetê-lo ao estado servil.

Contudo, o terceiro e quarto versos do primeiro canto-poema, sobrepondo-se às marcas dos primeiros versos, e, no segundo, o refrão, sobrepondo-se à estrofe, contrapõem-se, atualizando a história, a partir de um outro patamar histórico: "aqui, quem manda, é os nagô" e " una fuerza popular vamos todos a formar". Essas assertivas nos remetem ao princípio dinâmico de uma existência individualizada, concebida como Ésú, aquele que não teme os enfrentamentos, "Olódùmaré fez Èsú como se fosse um medicamento de poder sobrenatural próprio para cada pessoa. Isso quer dizer que cada pessoa tem à mão seu próprio remédio de poder sobrenatural, podendo utilizá-lo para tudo o que desejar" (SANTOS, 1976, p. 131). A essência que emana do tambor que convoca à batalha, à liberdade, é a de Ėsú, pois, na América, os cantos-poemas e os "tambores no sólo se volvieron el centro de La festividad[...], sino que se convirtieron en instrumentos para convocar a lashuidas y rebeliones" (VANÍN, ET ALI, 2010, p. 12), com sua voz ancestral.

A poeta afro-colombiana Mary Grueso, imersa nessa realidade totalizante que habita o seu corpo-resistência, traz a significância dessa voz ancestral:

\author{
Voz ancestral \\ Siento que mi corazón es una marimba \\ que no hace más que tocar melodías al alma \\ el currulao me mueve los pies \\ y una y otra vez oigo muy cerca \\ el sonido del guasá repicando en mí \\ y el bombo me llama desde el otro mar \\ con voz melancólica pregonando equidad. \\ La sangre corre \\ formando un concierto en mi interior \\ y de pronto, mi boca empieza a lactar \\ palabra tras palabra \\ de un canto ancestral. \\ ¡Levántate negra! \\ Me ordena una voz \\ desde lo más profundo de mi interior \\ ¿No oíste la marimba? \\ ¿Ni tampoco el guasá? \\ ¿El cununo no te vino a invitar?
}

Página | 110 
¿El bombo pregonero no oíste sonar?

No te hagas la sorda al llamado ancestral (GRUESO, 2015, p. 39).

A palavra de comando, matriz e motriz dos fios norteadores da tradição que prefiguram saberes há muito desenvolvidos, outorga aos descendentes a força para os enfrentamento por essência divinatória e, como "palavra do mago", torna aqueles que a detêm agentes de magia com o poder de "lançar felicidade ou infelicidade sobre aqueles a quem são destinados" (DERRIVE, 2010, p. 39). Sim, o canto-poema, transmutado em palavra tambor incomoda, pois o entendemos como "el máximo elemento de resistência" (LAVIÑA, 2005, p. 59) do povo afrodescendente, como se evidencia no canto-poema "Não mexe com povo de Angola":

\author{
Não mexe com povo de Angola, \\ Não mexe com povo de Angola, \\ Maria quem pega com Deus tem vitóriêêê \\ Você que falava de macumba \\ Você que falava de macumba \\ Macumbeiro, cuidado minha, \\ Feiticeiro, êêê (SANTANA, 2014, p. 228).
}

A pertença ancestral reveste o sujeito da palavra-força. Como explicita dona Faustina, "os cantos que vem puxano esse êêê é deles, os nagô africano" (SANTANA, 2014, p. 174), o que Zumthor (2010) considera como ideofones, ou seja, ideias-sons presentes nas línguas africanas. Segundo Hampatê-Bâ "a tradição, confere à Kuma, à Palavra, não só um poder criador, mas também, a dupla função de conservar e destruir. Por essa razão, a fala, por excelência, é o agente ativo da magia africana" (2010, p. 173). Assim, o canto-poema, também como elemento de resistência, implica uma presença que se expressa, se faz conhecer e busca atingir o expectador-ouvinte, como observamos nesse canto-poema nortecaucano:

Oye mi negrita, mi abuelo me dice

Que por allá por África están mis raíces

Óyeme, vamos a hacer historia

Oye bien, que nos llene de gloria (VELASCO DÍAZ, 2011, p. 222)

O canto-poema indissociável ao ritmo dos tambores fissuram-suturam os elementos em amálgama, no vibrar silencioso da memória e dos corpos que, através da identificação pelo espectador-ouvinte, ritualiza e reatualiza a tradição. A mensagem ritmada penetra o corpo, tornando-o multiplicado devido à sua relação de pertencimento a seu povo, sua ancestralidade. Essa relação entre o canto-poema e os sujeitos tem propiciado, no percurso da história, formas ritualísticas de linguagem, "“em novos e diferenciados rituais de linguagem e expressão, coreografando a singularidade e alteridades negras (MARTINS, 1997, p. 26).

Assim, articular o passado e o estatuto de descendência nessa América de invasão, lutas e resistências históricas, torna-se necessário, pois tanto a invisibilidade, quanto a folclorização podem colocar em risco a existência da tradição, com o perene processo usurpador de colonização com seus nomes 
ressignificados. Por isso, o canto-poema, ao mesmo tempo em que é lugar da palavra tecida como divina, da glorificação ancestral, da rebeldia e da harmonia, é também o lugar da palavra dor, desalento (SEMEDO, 2010), para que, através das memórias do tempo contado e vivido enunciem o processo que vilipendiou dos africanos o direito de se afirmarem enquanto um povo, o direito de celebrar sua teogonia e o direito à terra.

O canto de bunde "Mi amo me manda", ao referendar Chocó", uma região do Pacífico colombiano rica em minérios de ouro e prata, revela o local para onde "los esclavistas llevaban los africanos desde el Norte del Cauca a las minas que tenían en la Costa Pacífica [...] los africanos asumían el viaje para la Costa Pacífica como un castigo" (VELASCO DÍAZ, 2011, p. 268-269). Esse canto-poema responsivo, ao cantar a história da escravidão, mantém viva a força simbólica demonstrada no seu persistente poder de resistência, vindo a configurar e a expressar uma identidade do povo africano e seus descendentes na diáspora.

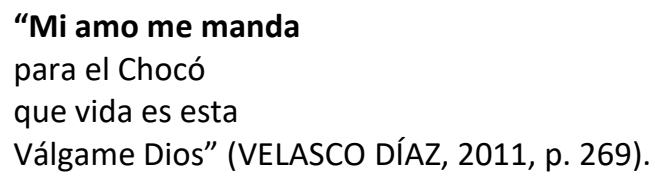

Ainda sobre o espaço da escravidão na Colômbia, Zambrano corrobora as palavras de Velasco Díaz:

Los destinos de los esclavos que llegaron a Colombia fueron sobre todo los sectores de los ríos Magdalena y Cauca y la Costa del Pacífico, con el fin de ejercer trabajos de minería en las zonas bajas de la costa y de ganadería y agricultura en las zonas de hacienda, en las partes altas de los ríos. Así fue como el trabajo de los esclavos africanos hizo prosperar las grandes haciendas del Viejo Cauca, hoy departamentos de Chocó (ZAMBRANO, 2003, p. 5).

A exemplo de Chocó, metáfora de castigo, a Colônia Leopoldina, segundo relato dos quilombolas, era um lugar de grande atrocidade para os negros escravizados, fato denunciado no canto-poema "No tempo de cativeiro". Como forma de luta e resistência, notamos que o canto-poema busca reconstruir um todo, particular e totalizante, ao procurar os cacos complementares da memória, "limpando-os da poeira acumulada" (VIEIRA, 1987, p. 9), que a história eurocentrista, sob a égide do colonizador, não quis revelar, mas sobreviveu impresso nas memórias de memórias.

\section{No tempo de cativeiro \\ Quando escravo sofria \\ Gritava pro Deus do céu \\ Quando chicote doía}

Eu tenho pena, loiô, eu tenho dó

De ver meus fio, loiô

Em dendecô (SANTANA, 2014, p. 231). 
As palavras que anunciam e denunciam o passado tão presente, considerando a arte poética que norteia os cantos-poemas, revelam que os vestígios da tradição estão "presentes de muitas maneiras nas coisas narradas, seja na qualidade de quem as viveu, seja na qualidade de quem as relata" (BENJAMIN, 2011, p. 221). As palavras são agentes da magia e, conforme nos assegura Juana Elbein dos Santos (1976, p. 46) "se a palavra adquire tal poder e ação, é porque ela está impregnada de àse, [...], acompanhada das modulações, da carga emocional, da história pessoal e do poder daquele que a profere". Os cantos-poemas, pela própria dinâmica de experimentação e criação, é tanto uma tira de tecido que se acumula e se enrola em um bastão que repousa sobre o ventre do tecelão, representando o passado, como o rolo do fio a ser tecido, que simboliza o mistério, o desconhecido devir ou, ainda, as provocações e os chamamentos à resistência no tempo e no espaço (SANTANA, 2014). Tiras de tecido, os cantos-poemas são transmutados em palavras cantadas que retiram o pó dos escombros e os estilhaços da memória.

\section{À GUISA DE CONCLUSÃO}

As marcas de ancestralidade do povo negro, como o canto do galo, poetizado por João Cabral de Melo Neto no poema "Tecendo a manhã", ao longo do tempo, foi tecendo os fios da memória de memórias, partilhadas nas litanias, nas festanças e no cotidiano existencial afrodescendente. Essa tessitura, por nós compreendida como tradição, ora fio, ora o próprio tear, construiu caminhos etéricos que reconduziram muitos povos ao seu berço territorial, à sua terra, à sua gente e, sobretudo, à sua teogonia. Através do polo irradiador, "outros mundos, outras formas de pensar e agir, enfim, outras formas de vida" (SANTOS, 2006, p. 325 ) foram apresentados à América, aos negros da terra e ao colonizador que em vão tentou esfacelar a força imanente da ancestralidade africana. Esse fato levounos a pensar nos possíveis diálogos, lutas e resistências na diáspora negra de colonização lusa e hispânica.

Este estudo sistemático acerca das composições sacro-poéticas almeja reconhecimento a partir de uma singularidade constituída no tempo e que delineia de forma diferente o ser e o agir afro-latino, por meio de manifestações musicaisreligiosas, e dá visibilidade às formas de resistência e manutenção de uma identidade construída ao longo dos enfrentamentos identitários ou dos jogos de poder, por vezes explícitos e muitas vezes velados, de modo a revelar que a poética da oralidade imprimiu no tempo e no espaço marcas de luta e resistência durante o processo dito civilizatório europeu.

O estudo dos cantos-poemas, uma tradição das comunidades quilombolas do Extremo Sul da Bahia, e o possível diálogo com os cantos ancestrais do Valle Del Cauca, Região do Pacífico colombiano, pouco a pouco corporificou-se como tema e problemática para esse trabalho. Então, que papel esses cantos, a partir de seus discursos e vozes sociais, poderiam revelar e o que permanece em silêncio em relação a esses territórios, sua história e sua gente? As respostas ainda carecem de muitas outras escritas e, quiçá, outros olhares e perspectivas, tendo em vista as multiplicidades oceânicas e rítmicas que referendam os cantos-poemas em sua construtividade e referencialidade poética. Entretanto, a partir dos estudos, apreendemos a importância que tiveram para a manutenção identitária e de resistência ao processo colonizador na América lusa e hispânica. 
Também, compreendemos que o ritmo é um fator importante à poética afrodescendente, pois traz o registro sagrado ancestral em que o passado se torna presente, revelando-se como "La arquitectura del ser, el dinamismo interno que le da forma, el sistema de ondas que emite endirección a los Otros, la expresión pura de la fuerza vital. [...]el impacto vibratorio, la fuerza que, a través de los sentidos, nos integra en la raíz del ser (SENGHOR, 1970, p. 221).

Ademais, entendemos a proximidade nas latitudes poéticas entre as comunidades quilombolas do Extremo Sul da Bahia e do Valle Del Cauca, no Pacífico colombiano. Os cantos ancestrais, por nós denominados de cantospoemas, é uma forma ritual, litania fúnebre, uma performance, marca de festividade, movimento ao trabalho. É uma individualidade totalizante, por isso, a nossa análise, por vezes, apenas tocou de soslaio o que ele comunica, por entendêlo como repositório da tradição, na qual se reverencia as entidades-símbolos, e, como tal, apropriando-nos das reflexões de Santos (1976, p. 182), "não é um elemento que se traduza, que se defina de maneira estática, mas elemento que se interpreta na medida em que é inserido em determinado contexto". Esse texto, mesmo na opacidade de sua escrita, deseja tomar "la dimension metafísica de um puente lumínico entre África, Colômbia (FRIEDEMANN, 1996, p. 147)" e Brasil, para entendermos nossas latitudes poéticas, nossa terra e história, nossas sacralidades ancestrais afro-latina-americana. 


\title{
Cuando canto es rezo, cuando rezo es canto: identidades negras y sacralidades poéticas
}

\begin{abstract}
RESUMEN
Los cantos-poemas, construidos a partir de experiencias intersubjetivas, son a veces respuestas, a veces preguntas a circunstancias históricas y socio-afectivas y a enfrentamientos de la vida diaria debido a su sacralidad. Describir esta poética en lo que aporta de expresiones que tratan de la representación del patrimonio africano, sus identidades, resignificaciones y resistencias, constituye un objeto de estudio de la trayectoria discursiva metodológica de este texto. En esta obra se destaca el papel que el canto-poema revela en relación con la comunidad quilombola del extremo sur de Bahía y las comunidades negras de la región del Pacífico del Valle del Cauca. Los análisis que sustentan esta obra dialogan con las teorías de la tradición viva, la poética de la oralidad y los estudios culturales. El poema canta, como instrumento poético, historias ancestrales explícitas, alabanzas y oraciones.
\end{abstract}

PALABRAS CLAVE: Canto-poema. Religiosidad. Resistencia. Ancestros. 


\section{NOTAS}

${ }^{1}$ Os diolas de Kong, que são um dos componentes da vasta zona Mandinga à qual eles se ligam linguística e culturalmente, estão situados ao norte da Costa do Marfim. Kong é a antiga capital do reino Diola, que foi fundada no século XVIII por SékouWatara (DERIVE, 2010).

2 De acordo com Cascudo (1954) e Carneiro (1954), o termo, grafado Kalunga, se repete com frequência nas línguas bantu. Em quioco, significa mar e, "no quimbundo, tratamento de pessoa ilustre [...]; a morte, o inferno, o oceano, Senhor, exclamação de surpresa e de encanto" (CASCUDO, 1954, p. 147).

${ }^{3}$ De acordo com Santos (1976, p. 183), o terceiro elemento, Èsú, “é o único capaz de desencadear qualquer ação e comunicar as partes entre elas".

${ }^{4}$ Sobre o culto, organização e simbologia nagô, ver: (SANTOS, 1976).

${ }^{5}$ De acordo com Santos (1976, p. 182), "uma entidade-símbolo não é um elemento que se traduza, que se defina de maneira estática, mas elemento que se interpreta na medida em que é inserido em determinado contexto".

${ }^{6}$ Palavra antiga ou discurso antigo, de uso diola, povos que situam no norte da Costa do Marfim.

${ }^{7}$ Chocó "es el área de mayor predominio de las supervivencias negras africanas [...] Las expresiones negras, de auténtica reminiscencia africana, se manifiestan alegres y explosivas como el mismo ardor de la raza, y con un profundo fondo de tristeza y sátira, que se patentiza en la música por los sonidos y voces que en forma de queja, muestran la tragedia de una raza esclavizada por los europeos en el laboreo de las minas y el trabajo de las haciendas y plantaciones (OCAMPO, 2000, p. 137).

\section{REFERÊNCIAS}

BENJAMIN, Walter. Magia e técnica, arte e política: ensaios sobre literatura e história da cultura. São Paulo: Brasiliense, 2011.

CUTI, Luiz Silva. In: Cadernos Negros 25: poemas afro-brasileiros. São Paulo: Quilombhoje, 2002.

DERRIDA, Jacques. A farmácia de Platão. São Paulo: Iliminuras, 2005.

DERIVE, Jean. Oralidade, literalização e oralização da literatura. Belo Horizonte: FALE/UFMG, 2010.

FRIEDEMANN, Nina S. de. Huellas de africania en Colombia: nuevos escenarios de investigación. In: Thesaurus. Tomo XL VII. N 3, 1992. 
. Luanda, Shiluango, Cabinda y Benguelaen «La ruta del esclavo».

IN: América negra. Pontifícia Universidad Javeriana. No 12 Bogota,

Colombia, diciembre de 1996.

De la tradición oral a la etnoliteratura. In: América negra.

Universidad Javeriana. No 13, Bogota, Colombia, junio de 1997.

GRUESO, Mary. Cuando los ancestros llaman: poesía afrocolombiana.

Popayán: universidad del Cauca/ Sello Editorial, 2015.

HAMPATE BÂ, A. A tradição viva. In: KI-ZERBO, Joseph (editor).

História geral da África: metodologia e pré-história da África. Brasília:

UNESCO, 2010.

LAVIÑA, Javier. Esclavos rebeldes y cimarrones. IN: ANDRÉS-

GALLEGO, José. Tres grandes cuestiones de la historia de

Iberoamérica: ensayos y monografías.Madri: Fundación MAPFRE, 2005.

MARTINS, Leda Maria. Afrografias da memória: o reinado do rosário do Jatobá. São Paulo: Perspectiva; Belo Horizonte: Mazza, 1997.

MOÑIMO, Yves. SCHWEGLER, Armin. Palenque, Cartagena y Caribe: historia y lengua. Tübingen: Niemeyer, 2002.

OCAMPO, Javier. Musica y folclor de Colombia. Colombia: Cuatro por Cuatro Editores Ltda, 2000.

PADILHA, Laura Cavalcante. Entre voz e letra: o lugar da ancestralidade na ficção angolana do século XX. Rio de Janeiro: Pallas, 2007.

PEREIRA, Edimilson de Almeida; GOMES, Nubia Pereira de Magalhães. Flor do não esquecimento: Cultura popular e processos de transformação.Belo Horizonte: Autêntica, 2002.

SANGHOR, Leopold Sedar. Libertad, negritud y humanismo. Madri: Editorial Tecnos S.A, 1970.

SANTANA, Gean Paulo Gonçalves. Entre o dito e o não dito: conflitos e tensões na refundação territorial quilombola. Dissertação de mestrado. $\mathrm{UNEB} / 2008$.

Vozes e versos quilombolas: uma poética identitária e resistência em Helvécia. Tese de doutorado. Pontifícia Universidade Católica do Rio Grande do Sul- PUCRS/2014.

SANTOS, Juana Elbein dos. Os Nàgô e a morte: Pàde, Àsèsè e o Culto Égun na Bahia. Petrópolis: Vozes, 1976.

SCHAFER, Murray. O ouvido pensante. São Paulo: UNESP, 1992. 
SEMEDO, Odete Costa. As Mandjuandadi: Cantigas de mulher na Guiné-Bissau: Da tradição oral à literatura. Tese de doutorado apresentada à UFMG. Belo Horizonte, 2010.

VANÍN, Alfredo et ali. Plan especial de salvaguardia (pes) de las músicas de marimba y los cantos tradicionales del pacífico sur de Colombia. Bogotá: Ministério da Cultura, 2010.

VANSINA, J. A tradição oral e sua metodologia. In: KI-ZERBO, Joseph (editor). História geral da África: Metodologia e pré-história da África. Brasília: UNESCO, 2010.

VELASCO, Carlos Alberto. Comunidad, Cultura y etnoeducación afrocolombiana: Cantos ancestraes de jugas, bundes, romances del norte del Cauca y sur del Valle del Cauca. Santiago de Cali: Universidad del Valle/ Faculdad de Humanidades, 2011.

VELASQUEZ M. Rogerio. Instrumentos musicales del alto y bajo Choco. IN: Revista Colombiana de folclor. Bogotá, vol. II, Nº 6, 1961.

VIEIRA, Yara Frateschi. Poesia medieval: Literatura portuguesa. São Paulo: Global, 1987.

ZAMBRANO, Catalina. Música, identidad y muerte entre los grupos negros del Pacífico sur colombiano. Revista Universidad de Guadalajara, Ediciones Pandora, número 27 de La Colección de Babel, abril de 2003.

ZUMTHOR, Paul. Introdução à poesia oral. Belo Horizonte: Editora UFMG, 2010.

Recebido: 17 jul. 2020

Aprovado: 08 ago. 2020

DOI: $10.3895 /$ rl.v22n38.12774

SANTANA, Gean Paulo Gonçalves. Quando canto é reza, quando reza é canto: identidades negras e

sacralidades poéticas. R. Letras, Curitiba, v. 22, n. 38 p. 101-118, set. 2020. Disponível em:

$<$ https://periodicos.utfpr.edu.br/rl>. Acesso em: XXX.

Direito autoral: Este artigo está licenciado sob os termos da Licença Creative Commons-Atribuição 4.0 Internacional.

\section{(c) (i)}

